\title{
PERAN DUTA WISATA ONGGA BALE KABUPATEN POSO DALAM MEMAJUKAN EDUKASI PARIWISATA DI ERA GLOBALISASI
}

\author{
Martho Harry Melumpi \\ Email : harrymelumpi@ rocketmail.com \\ Program Studi Agribisnis Universitas Kristen Tentena
}

\begin{abstract}
Abstrak
Keindahan alam Indonesia, yang dihuni oleh berbagai etnik dengan keragaman budaya yang khas sangat mendukung pengembangan sektor pariwisata. Duta wisata Ongga Bale Kabupaten Poso memiliki peran cukup penting bagi kepariwisataan. Dengan cara mempromosikan obyek-obyek wisata lewat berbagai media, hal ini dinilai cukup efektif untuk menarik sejumlah wisatawan untuk datang berkunjung, salah satunya adalah dengan memajukan edukasi pariwisata dalam era globalisasi dimana menuntut kualitas yang baik dari peran Ongga Bale itu sendiri. Pengaruh globalisasi akibat perkembangan teknologi informasi yang diikuti dengan kemudahan akses membuat pergerakan manusia menjadi lebih cepat, lebih bervariasi, lebih nyaman, lebih ekonomis, dan lebih mudah.Dalam wisata edukasi, bukan hanya kesenangan dan kepuasaan hati yang di dapat ketika selesai melakukan kegiatan wisata, namun ditambah dengan ilmu pengetahuan. Penyebab minimya edukasi pariwisata yang dimiliki oleh Ongga Bale diharapkan untuk terus belajar agar dapat mewakili daerahnya dalam upaya memajukan potensi dan aset wisata daerahnya. Kemanapun ia berpergian, ia pun berkewajiban untuk tetap mempromosikan dan mensosialisasikan potensipotensi yang ada di daerahnya. Dan dengan fungsinya sebagai media tersebut, Ongga Bale harus menguasai benar atas apa saja yang ada didaerahnya tersebut.Beberapa dampak pengembangan yang dapat ditemui tentang bagaimana para duta pariwisata ini adalah kemampuan mereka menjadi inovasi dan kreativitas.
\end{abstract}

Kata Kunci : Duta Wisata Ongga Bale, Edukasi Pariwisata, Globalisasi

\begin{abstract}
The natural beauty of Indonesia which is inhabited by various ethnic groups with distinctive cultural diversity will support the development tourism sector. The Ongga Bale of Poso District has an important role for tourism. It promotes tourism objects through a variety of media. It is considered effective enough to attract a number of tourists to come to visit Poso. One of which is to promote tourism education in the era of globalization which demands a good quality of Bale Ongga role itself. The influence of globalization due to the development of information technology, followed by ease of access make human movements become faster, more varied, more comfortable, more economical, and more mudah.Dalam educational tourism, not only pleasure and satisfaction in liver can be when finished tourism activities, but coupled with science. Causes of tourism education minimya owned by Ongga Bale is expected to continue to learn in order to represent the area in an effort to promote the potential and regional tourist asset. Wherever he traveled, he was obliged to continue promoting and disseminating the potentials that exist in the region. And to function as the media, Ongga Bale must be mastered on what is its region tersebut.Beberapa development impact that can be found about how the tourism ambassador is their ability to be innovative and creative.
\end{abstract}

Keywords: Tourism Ambassador Ongga Bale, Tourism Education, Globalization 
PENDAHULUAN

Pariwisata merupakan salah satu sektor yang dapat dijadikan sebagai andalan dalam meningkatkan devisa negara. Sektor ini merupakan industri yang dapat berkembang dan tahan terhadap berbagai terpaan. Berdasarkan kondisi tersebut tidak mengherankan apabila tiap daerah tujuan wisata berlomba dan berbenah diri. Sikap kompetisi tersebut harus disikapi positif dengan semangat bersaing yang semakin gigih dari berbagai pihak yang terkait dalam sektor ini.Keindahan alam Indonesia, yang dihuni oleh berbagai etnik dengan keragaman budaya yang khas sangat mendukung pengembangan sektor pariwisata. Dunia usaha yang berorientasi kepada jasa pelayanan pariwisata diyakini memberi pengaruh yang besar kepada sektor ekonomi lainnya karena mempunyai sifat yang multidimensi. Maraknya kompetisi Duta Wisata serta beragam bentuk pemilihan ikon kebudayaan dan pariwisata lainnya sebagai upaya memilih brand ambassador merupakan fenomena yang sering dijumpai akhir-akhir ini baik dalam skala lokal, regional, nasional, bahkan internasional. Pemilihan Duta Wisata dilakukan sebagai upaya menciptakan dan mengomunikasikan citra merek yang merupakan bagian dari pengembangan strategi pemasaran sebuah wilayah di era modern.

Untuk menyikapi adanya faktor yang mampu mempengaruhi adanya wisatawan yang dapat berkunjung diperlukan adanya informasi yang akurat, efektif, dan efisien. Informasi tersebut bisa mudah disampaikan dengan adanya figur yang mampu bekerjasama dengan dinas terkait untuk membantu promosi wisata suatu daerah. Untuk mempromosikan daerah wisata diperlukan usaha nyata yang bisa menyampaikan informasi pariwisata bisa mudah disampaikan. Dengan adanya figur yang mampu bekerjasama dengan dinas terkait untuk membantu mempromosi wisata suatu daerah. Sosok yang dirasa cukup mempuni dalam mempromosikan pariwisata daerah adalah duta wisata. Duta Wisata didefinisikan sebagai remaja berusia 17sampai dengan 25 tahun yang bisa diikuti oleh Warga Negara Indonesia. Mereka diharapkan menjadi citra teladan generasi muda yang dinamis, kreatif dan cerdas. Sekaligus berperan sebagai ujung tombak Dinas Kebudayaan dan Pariwisata dalam mempromosikan potensi pariwisata yang ada. Kata kunci dari definisi ini sudah jelas, bahwa yang menjadi titik bidik adalah remaja putra ataupun putri yang memiliki kompetensi diri yang tahan saing. Bahwa 
duta wisata merupakan perpanjangan tangan pemerintah dalam upaya memperkenalkan potensi pariwisata dengan tujuan dapat meningkatkan kunjungan wisatawan baik lokal maupun asing, pemilihannya dilakukan rutin setiap tahunnya.(sumber:http://dompu.info/dutawisata-media-promosi-salah-kaprah-dansalah-arah,28 maret 2012).

Akan dirasa memprihatinkan bilamana ada suatu potensi wisata yang mampu menjadi maju dan berkembang malah kurang mendapatkan perhatian dari pubik maupun dari dinas terkait. Dengan adanya ajang pemilihan duta wisata nantinya diharapkan terpilihnyasosok yang mampu menjadi sorang promotor yang mampu mempromosikan potensi wisata yang ada di daerah tersebut, salah satunya dengan memiliki wawasan edukasi pariwisata yang dapat digunaka diera globalisasi ini. Salah satu ajang pemilihan duta wisata yang ada di Kabupeten Posoadalah Pemilihan Ongga Bale Kabupaten Poso yang mana diharapkan memiliki peran yang signifikan dalam memperkenalkan Pariwisata Kabupaten Poso, dengan permasalahan tersebut maka penulis hendak menjelaskan tentang "Peran Duta Wisata Ongga Bale Kabupaten Poso dalam Memajukan Edukasi Pariwisata di Era Globalisasi"

\section{KAJIAN PUSTAKA}

Meningkatnya pendidikan seseorang menyebabkan adanya kecenderungan di masyarakat dalam melakukan perjalanan berwisata, yaitu memilih berwisata yang dapat memperoleh pengalaman baru selama perjalanan. Hal ini menunjukkan ada perubahan minat wisata yang mengarah pada proses pembelajaran selama perjalanan wisata (misalnya, wisata yang dipandu oleh ahli ekologi atau sejarah). Kelompok kelompok wisatawan minat khusus ini tertarik mengunjungi kawasan yang dilestarikan, menjadi eko-turis, yang cenderung untuk menjadi wisatawan yang memperoleh banyak pengetahuan dibandingkan wisatawan pada umumnya (Kusudianto, 1996). Dewasa ini dalam era globalisasi, peran ilmu pengetahuan juga berhubungan erat dengan kebudayaan. Ilmu pengetahuan adalah produk budaya. Oleh karena itu ia dapat menjalankan fungsinya dengan tepat, apabila diletakkan dalam kontekbudaya. Ini berarti, pertumbuhan dan perkembangannya terjadi berkat dukungan faktor-faktor budaya lainnya. Artinya, ilmu pengetahuan akan maju dan mundur, sejauh kondisi yang mengelilinginya memberikan dorongan baginya untuk berkembang atau menghambatnya. Begitu juga dengan sektor pariwisata, sektor pariwisata juga 
menghasilkan sub bagian baru yaitu wisata edukasi. Dalam wisata edukasi, bukan hanya kesenangan dan kepuasaan hati yang di dapat ketika selesai melakukan kegiatan wisata, namun ditambah dengan ilmu pengetahuan.

Pembangunan sektor pariwisata yang dilakukan dengan baik dan maksimal akan mampu menarik wisatawan domestik maupun wisatawan asing untuk datang dan membelanjakan uangnya dalam kegiatan berwisatnya. Dari transaksi itulah masyarakat daerah wisata akan terangkat taraf hidupnya serta negara akan mendapat devisa dari wisatawan asing yang menukar mata uang negaranya dengan rupiah. Tujuan pembangunan pariwisata, bukan hanya sekedar peningkatan perolehan devisa bagi negara, akan tetapi lebih jauh diharapkan pariwisata dapat berperan sebagai katalisator pembangunan (agen of development). Mewujudkan pariwisata yang berkesinambungan, merupakan sebuah usaha yang tidak hanya dilakukan oleh satu unsur, melainkan gabungan dari semua unsur-unsur yang terkait, baik dari pemerintah, masyarakat, hingga instansiinstansi pendukung pariwisata. Menurut World Economic Forum, pada tahun 2011 Indonesia menempati urutan ke 74 untuk tujuan pariwisata dari 133 tujuan pariwisata di seluruh negara di dunia dan menempati urutan ke 13 dalam urutan Asia Pasifik. Tujuan utama yang dituju pertama oleh para wisatawan asing maupun lokal di Indonesia adalah Bali, urutan ke dua ditempati kotakota di Jawa Barat sedangkan sisanya adalah kota-kota lainnya di luar Pulau Jawa (Gunawan, 1997).

Pendidikan dan edukasi memiliki pengertian yang berbeda, pendidikan adalah pengubahan sikap dan tata laku seseorang atau kelompok orang dalam usaha mendewasakan manusia melalui upaya pengajaran dan latihan, proses, perbuatan, dan cara mendidik (Ankomah, 1992). Sedangkan pengertian edukasi adalah upaya dari subyek terhadap objek untuk mengubah cara memperoleh dan mengembangkan pengetahuan menuju cara tertentu yang diinginkan oleh subyek, (Suroso, Rendra. 2004).Secara entimologis, edukasi beraal dari kata latin yaitu educare yang artinya "memunculkan", "membawa", “melahirkan". Dalam pengertian secara luas edukasi adalah setiap tindakan atau pengalaman yang memiliki efek formatif pada karakter, pikiran atau kemampuan fisik dalam individu.

Pada kedua pengertian tersebut dapat diambil kesimpulan bahwa pendidikan lebih terarah kepada kelompok manusia akan 
tetapi pengertian pendidikan lebih dikerucutkan kepada individu itu sendiri. Edu-Tourism atau Pariwisata Pendidikan dimaksudkan sebagai suatu program dimana peserta kegiatan wisata melakukan perjalanan wisata pada suatu tempat tertentu dalam suatu kelompok dengan tujuan utama mendapatkan pengalaman belajar secara langsung terkait dengan lokasi yang dikunjungi (Ankomah, 1992). Program Pariwisata Pendidikan dapat berupa ekowisata (ecotourism), wisata warisan (heritage tourism), wisata pedesaan/pertanian (rual/farm tourism), wisata kominitas (community tourism) dan pertukaran siswa antar institusi pendidikan (student exchanges).

Komitmen untuk menjadi Duta Wisata yang memiliki kualitas baik dan mengamati perkembangan pariwisata minat khusus terutama yang berkaitan dengan pendidikan, peran duta wisata Ongga Bale Kabupaten Poso akan mengadakan kerjasama dengan berbagai institusi mengemas program Educational Tourism dengan memadukan pendidikan sesuai minat wisatawan dan kegiatan sosial budaya sehingga program dapat terkolaborasikan dengan baik. Dalam rangka mengembangkan obyek wisata perlu segera dilaksanakan inventarisasi terhadap potensi nasional obyek wisata alam secara bertahap sesuai prioritas dengan memperhatikan nilai keunggulan saing dan keunggulan banding, kekhasan obyek, kebijaksanaan pengembangan serta ketersediaan dana dan tenaga. Namun sebenarnya, duta pariwisata atau tourism ambassador merupakan credible testimony yang merupakan karakter unik, mewakili tempat serta daya tarik wilayah yang direpresentasikan, diharapkan memberikan pengaruh kepada banyak pihak melalui jaringan dan hubungan yang mereka miliki dari visi misi dan program kerja sosial mereka. Ongga Bale Kabupaten Poso adalah suatu sebutan untuk Duta Wisata di Kabupaten Poso. Sebutan ongga untuk perempuan dan Bale untuk laki-laki.

Potensi daerah obyek wisata alam yang sudah ditemukan segera diinformasikan dan dipromosikan kepada calon penanam modal. Perlu dikembangkan sistem kemitraan dengan pihak swasta, lembaga swadaya masyarakat yang ada, dalam rangka mendukung optimalisasi pengembangan obyek wisata alam. Peranan pemerintah daerah dalam pengembangan obyek wisata alam sangat penting, dengan melaksanakan koordinasi, perencanaan, pelaksanaan serta monitoring pengembangan obyek wisata alam. 


\section{METODOLOGI PENELITIAN}

Jenis penelitian ini adalah penelitian lapangan (field research) dengan metode kualitatif melalui pendekatan deskriptif hal ini sesuai dengan pendapat (Sugiyono, 2007) menjelaskan "Pendekatan deskriptif adalah penelitian yang berusaha menggambarkan dan menginterpretasi objek sesuai dengan apa adanya".

Menurut Moleong (2009: 6) menjelaskan"Metode penelitian kualitatif adalah metode penelitian yang bermaksud untuk memahami fenomena tentang apa yang dialami oleh subjek penelitian misalnya perilaku, persepsi, motivasi, tindakan, dll, secara holistik, dan dengan cara deskripsi dalam bentuk kata- kata dan bahasa, pada suatu konteks khusus yang alamiah dan dengan memanfaatkan berbagai metode alamiah. Jadi penelitian yang penulis lakukan adalah penelititian yang bermaksud untuk mengetahui tentang peranan duta wisata dalam memajukan pariwisata di Kabupaen Poso.

\section{HASIL DAN PEMBAHASAN}

Pariwisata merupakan salah satu sektor yang sangat diandalkan dalam pembangunan nasional karena pariwisata dapat meningkatkan pendapatan nasional dan pendapatan daerah serta devisa negara. Pariwisata juga berperan dalam menciptakan lapangan kerja dan mengurangi pengangguran sekaligus menciptakan kesejahteraan masyarakat. Di dalam realitanya, sektor pariwisata dijadikan sebagai alat untuk menormalkan kembali ekonomi Indonesia yang kurang stabil. Untuk mendukung sektor pariwisata, maka diperlukan adanya partisipasi dari masyarakat dan keprofesionalan dari pihak pengelola pariwisata itu sesuai dengan peraturan dan ketetapan yang berlaku. Di samping itu dengan adanya perhatian yang serius dari pemerintah terhadap kepariwisataan, maka usaha di bidang kepariwisataan di Indonesia diharapkan berkembang dengan baik.Pariwisata adalah kegiatan yang tidak mengenal batas ruang dan wilayah (borderless). Pengaruh globalisasi akibat perkembangan teknologi informasi yang diikuti dengan kemudahan akses membuat pergerakan manusia menjadi lebih cepat, lebih bervariasi, lebihnyaman, lebih ekonomis, dan lebih mudah.

Kabupaten Poso adalah salah satu kabupaten yang berada di Provinsi di Sulawesi Tengah yang beribu kota Poso. Posisi Kabupaten Poso terletak ditengahtengah pulau Sulawesi yang merupakan jalur strategis yang menghubungkan antar provinsi di pulau Sulawesi.Setelah menjadi 
induk pemekaran dua kabupaten yaitu Kabupaten Tojo-Unauna dan Kabupaten Morowali, Kabupaten Poso saat ini memiliki luas $8.712,25 \mathrm{Km} 2$ atau 12,81 persen dari luas daratan Provinsi Sulawesi Tengah. Kabupaten Poso terdiri dari 19 Kecamatan (Data Kabupaten Poso, 2015).

Kabupaten Poso sendiri memiliki sektor andalan yaitu sektor pariwisata yang merupakan salah satu sektor unggulan startegis dan potensial. Keindahan kabupaten Poso menjadikan salah satu daerah tujuan wisata andalan Sulawesi Tengah, dimana setiap tahunnya di adakan iven nasional Festival Danau Poso di kota wisata Tentena. Hal ini juga memberikan kontribusi bagi pemerintah daerah untuk terus menata dan mebuat konsep yang menarik bagi wisatawan untuk datang berkunujung. Festival Danau Poso juga dirangkaikan dengan pesta rakyat "Padungku" dimana masyarakat Kabupaten Poso bersyukur atas panen hasil bumi yang sudah mereka lakukan dan salah satu acara didalamnya adalah Pemilihan Putra-Putri Duta Wisata Sulawesi Tengah yang sebagaian finalisnya adalah pemenang Ongga-Bale Kabupaten Poso yang bersaing dengan seluruh finalis dari kabupaten dan kota yang berada di Sulawesi Tengah. Sesungguhnya, tujuan pemilihan duta wisata sendiri sudah menyimpang dari tujuan awalnya, yang memilih duta wisata untuk mewakili kebudayaan daerahnya sendiri. Kebanyakan peserta menjadikan ajang ini sebagai pencarian popularitas dan tampil belaka. Beberapa pengetahuan yang mereka miliki tentang kebudayaan daerah hanyalah informasi seadanya dari bacaan-bacaan yang mereka hafalkan selama proses pemilihan. Walaupun tidak sedikit yang mengakui potensi individual dan karakteristik dari pemenang duta wisata tersebut. Namun, peranan dan kontribusi mereka sebagai duta wisata yang notabene "ikon"-nya daerah setempat, masih jarang kita dengar. Sementara ini, tugas duta wisata masih samar-samar, seharusnya dilakukan perubahan terhadap kriteria dan outcomenya supaya duta wisata dapat menjadi sebuah ajang yang benar-benar berguna. Terlebih pada kenyataannya, pemenangnya belum mampu membuktikan kalau mereka bisa mempertanggungjawabkan apa yang telah mereka dapatkan.

Hal ini juga memberikan pelajaran bagi para Finalis Duta Wisata Ongga Bale untuk memberikan edukasi lewat Presentasi Priwisata yang mereka paparkan di hadapan dewan juri. Dari hasil yang mereka paparkan sebagain Ongga Bale belum menguasai berbagai objek wisata yang ada di daerahnya 
sendiri dan ini yang membuat penulis tertarik bagaimana memberikan wawasan pengetahuan edukasi wisata kepada mereka lebih mendalam tentang budaya dan pariwisata di Kabupaten Poso terlebih dalam menantang zaman modern era globalisasi dimana mereka di tuntut lebih proaktif dalam mempromosikan pariwisata daerahnya lewat media sosial. Dimana kita tau bersama bahwa pengaruh media sosial sangat besar manfaatnya sebagai media yang cepat untuk berbagi keindahan objek wisata dalam beberapa saat saja.Hal ini yang harus dimanfaatkan secara baik dan maksimal sebagai Duta Wisata Pemenang Ongga Bale Kabupaten Poso, karena tugas mereka bukan hanya sebagai pajanganpenjemput tamu pejabat atau sebagai icon pada stand pameran yang dilaksanakan oleh dinas terkait. Sebagai tambahan, fakta bahwa duta wisata mayoritas berstatus pelajar dan mahasiswa, juga menyulitkan perkembangan ide dan kontribusi mereka karena kesibukan pribadi. Lain halnya apabila mereka dicutikan dan dipekerjakan untuk Dinas Pariwisata sebagai staf pengembangan dan promosi pariwisata.

Jadi untuk mengatakan bahwa duta wisata adalah pajangan, itu sangat tepat. Sebab, setelah event duta wisata mereka tidak diberdayakan dengan maksimal untuk keperluan Dinas Pariwisata, sehingga pada akhirnya hanya muncul pada saat acaraacara seremonial saja.Tapi tugas mereka adalah lebih dari itu dimana mereka diberikan ruang yang lebih banyak lagi seperti melakukan sosialisai di sekolah dan kampus, terjun langsung pada kegiatan sosial, memberikan pikiran ide-ide kreatif untuk kemajuan pariwisata Kabupaten Poso. Dari Pengamatan dan observasi yang penulis lakukan sebagaian Pemenang Duta Wisata Ongga Bale mau terjun langsung tanpa di berikan kompensasi dari kegiatan yang sudah mereka lakukan tapi mereka diberikan ruang dan kesempatan yang lebar untuk mengimplementasikan karya dan bakat mereka lewat edukasi pariwisata dimana sebagaian mereka adalah siswa dan mahasiswa. Salah satu bukti konkret yang sudah dilakukan oleh Duta Wisata Ongga Bale Kabupaten Poso adalah dengan berhasil menjadi Pemenang ke 2 pada lomba karya tulis ilmiah Perdamaian dan Pariwisata yang dilakasanakan oleh Bupati Poso Darmin A. Sigilipu oleh Bale Kabupten Poso Fotogenik 2015 sekaligus Putra Duta Wisata Favorit Sulawesi Tengah 2015 Ahmad Nabani. Hal-hal seperti inilah yang harus dikembangkan oleh pemenang Ongga Bale Kabupaten Poso untuk memberikan kontribusi yang bermanfaat 
untuk kemajuan potensi pariswisata dan dirinya sendiri serta dapat memerikan edukasi pariwisata bagi generasi muda.

Harapan kita, Ongga Bale ke depan semakin berkembang dan berfungsi sebagai duta pariwisata dan duta budaya. Sehingga bisa dilihat hasilnya bukan hanya dilihat dari segi umum saja. Karena kita tidak bisa menilai segala sesuatu hanya dari satu sudut pandang saja. Secara konkret, seorang presiden pun tidak semudah membalikkan telapak tangan dalam menjalankan dan mengatur sebuah negara. Apalagi hanya seorang duta wisata Ongga Bale yang tidak mudah mendapatkan segala fasilitas untuk melakukan promosi budaya dan promosi wisata. Namun, perlu diakui bahwa ajang pemilihan Ongga Bale dapat membawa perubahan dalam pribadi dan tingkah laku para generasi muda, karena setelah mengikuti ajang pemilihan duta wisata, rasa cinta budaya menjadi semakin mengental di dalam diri.

Mulai sekarang, seluruh duta wisata Ongga Bale harus dapat menunjukkan kalau memiliki niat baik dalam memberikan kontribusi bagi daerahnya, karena belum terlambat untuk memulai sesuatu yang baik. Andaikan tidak dilakukan, Ongga Bale hanya akan menjadi ikon pemborosan yang dilakukan oleh pemerintah daerah setempat yang tidak dapat meninggalkan kesan apa pun seperti hilang ditelan waktu.Penggunaan berbagai praktik pemasaran merupakan cara yang populer untuk mempromosikan daya tarik suatu wilayah baik itu untuk keperluan bisnis, wisata, dan pendidikan. Beberapa dampak pengembangan yang dapat ditemui tentang bagaimana para duta pariwisata ini adalah kemampuan mereka menjadi inovasi dan kreativitas. Hal ini terilustrasikan dalam berbagai event dan kegiatan yang mereka lakukan dengan banyak pihak di luar tugastugas fungsional mereka.

Edukasi Pariwisata yang diberikan oleh penulis sebagai bekal bagi para Duta Wisata Ongga Bale kabupaten Poso diantaranya adalah :

1. Mengenali dan mempromosikan objek wisata yang ada di Kabupaten Poso dengan mengangkat tema menarik diantaranya : The Legend Of Danau Poso (Wisata Air, kuliner dan mitos lokal lampu danaunya, memiliki ikan endemik sidat/sogili), Air luncur sulewana (telah dimanfaatkan sebagai PLTA PT.Poso Energy yang mampu mensuplai kebutuhan listrik di seluruh wilayah Sulawesi), The magnificient of saluopa waterfall (memiliki keindahan ekosisten air terjun 12 tingkat dan hutan hujannya), The majestic of Palindo 
Seppe (Berbicara soal iconicnya patung megalitik di balik sejuta misteri kisah dan kepercayaannya), The holly land of Napu village (Keindahan alam lembah Napu yang seperti pegunungan swiss, sejumlah artefak dan situs suci didalamya, The shining of Danau Tambing (Populer sebagai wisata alam dan perkemahan baru di Sulawesi Tengah). Berbagai tema ini adalah "The New Spirit Of Kabupaten Poso"

2. Penggunaan brand ambassador, merupakan fenomena kekinian yang sangat populer keberadaannya dalam dunia bisnis. Jaringan personal yang dibangun para Ongga Bale itu juga tidak hanya dianggap sebagai saluran komunikasi efektif, namun juga sumber daya tersirat dapat dimaksimalkan keberadaannya untuk meningkatkan daya saing umum sebuah wilayah.

3. Kampanye budaya di berbagai media sosial yang berupaya menyebarkan virus kecintaan terhadap budaya lokal kepada generasi muda. Hal yang secara intensif mulai dilakukan oleh para ikon pariwisata tersebut guna memberikan inspirasi dan semangat kepada masyarakat secara luas agar lebih menghargai dan mencintai kebudayaan yang dimiliki di tengah gempuran infiltrasi kebudayaan asing.

4. Dalam mempromosikan potensi pariwisata yang ada, perlu kiranya Ongga Bale ikut mempromosikan halhal penunjang, seperti kuliner dan kesenian khas Kabupaten Poso. Untuk itu Ongga Bale juga harus mampu menjelaskan dan mempromosikan dengan baik berbagai ragam dan jenis kuliner khas Poso, seperti inuyu, kue cucur, kue gepe, arogo onco, dan buah jongi.

5. Ongga Bale juga harus mampu mengenalkan dan dapat mempromosikan secara jelas dan gamblang berbagai kesenian khas Poso, seperti musik karambangan, geso-geso, tarian dero, tarian torompio, dan ceritera rakyat serta produk oleh-oleh kerajinan tangan kayu hitam ebony, selain itu juga perlu memperhatiakan oleh-oleh jajanan khas Poso karena belum ada.

Kabupaten Poso terkenal dengan semboyan " SINTUWU MAROSO “ yang bermakna Bersatu Teguh. Walaupun beberapa tahun lalu daerah ini mengalami konflik horizontal tapi saat ini kembali bangkit dengan terus membenah dan menata diri ke arah yang lebih baik dan membuktikan bahwa Kabupaten Poso sangat 
aman untuk dikunjungi dan melakukan perjalalan wisata. Oleh karena itu di sinilah peran para Duta Wisata Ongga Bale Kabupaten Poso sebagai icon geberasi muda untuk terus memajukan pariwisata daerahnya dari berbagai aspek salah satunya dengan terus mengkampanyekan edukasi wisata terlebih dalam menyongsong era globalisasi MEA (Mayarakat Ekonomi Asia).

\section{PENUTUP}

\section{Kesimpulan}

Duta wisata Ongga Bale adalah ikon atau figur pariwisata dan kebudayaan yang terpilih setelah melewati serangkaian proses seleksi yang dikemas dalam bentuk pemilihan yang diikuti oleh generasi muda atau remaja. Duta wisata Ongga Bale merupakan perpanjangan tangan pemerintah dalam upaya memperkenalkan potensi pariwisata dengan tujuan dapat meningkatkan kunjungan wisatawan baik lokal maupun asing dengan pendekatan edukasi pariwisata yang mereka miliki. Bersedia memperkenalkan produk dan potensi wisata Kabupaten Poso baik secara regional, nasional, maupun internasional. Dalam menjalnkan tugas dan peran sebagai Ongga Bale juga terdapat kendala dalam pelaksanaanya yaitu minimnya frekwensi pertemuan dengan anggota Ikatan Ongga
Bale yang lain, kurangnya kesadaran dan pengetahuan masyarakat serta rasa memiliki terhadap budaya dan pariwisata serta minimnya event pariwisata dan budaya untuk dapat mengaplikasikan potensi yang mereka miliki sebagai Duta Wisata Ongga Bale Kabupaten Poso. Minimnya edukasi pariwisata yang di miliki oleh para Ongga Bale diharapkan mereka untuk terus belajar dan menggali potensi diri, dengan memiliki wawasan edukasi para Ongga Bale nantinya dapat mengukir prestasi yang membanggakan untuk Poso sampai ke tingkat nasional.

\section{Saran}

Melihat apa yang sudah dijelaskan oleh penulis. Mulai dari pengertian pariwisata, promosi wisata, edukasi pariwisata, tugas dan peran duta wisata, kendalanya, kontribusi yang sudah dilakukan, dan pendapat masyarakat. Penulis ingin memberikan saran mengenai pelaksanaan pemilihan duta wisata Ongga Bale Kabupaten Poso yaitu pada waktu pembekalan seharusnya peserta juga diajarkan mengenai pemasaran dan promosi wisata lewat media sosial.Promosi juga memiliki fungsi yang bisa membujunk konsumen untuk dapat membeli produk wisata. Promosi juga mampu menambah nila 
sehingga bisa memberi citra baik bagi penawaran-penawaran mereka, inovasi, penyempurnaan kualitas, atau mengubah persepsi masyarakat mengenai peran duta wisata. Dengan berhubungan dengan baik duta wisata juga bisa menjalin komunikasi dan hubungan dengan masyarakat dan mitra kerja.Selain itu penulis juga menyarankan untuk pemerintah dan dinas terkait untuk introspeksi diri mengenai pemilihan duta wisata. Dengan berhubungan baik Ongga Bale juga bisa menjalin komunikasi dan hubungan dengan masyarakat dan mitra kerja.

\section{DAFTAR PUSTAKA}

Ankomah, P. K and Larson, T. R.1992. Education Tourism: A Strategy to Strategy to Sustainable Tourism Development in Sub-Saharan Africa. Available from: unpan1.un.org/intradoc/groups/publi c/documents
Dinas Pariwisata \&Kebudayaan Kabupaten Poso. 2015., Data Statistik Kabupaten Poso.

Gunawan, Myra. P., 1997, Perencanaan Pariwisata Berkelanjutan, ITB, Bandung.

http://dompu.info/duta-wisata-mediapromosi-salah-kaprah-dan-salah-arah, 28 maret 2012).

Kusudianto, Hadinoto. (1996). Perencanaan Pengembangan Destinasi Pariwisata. Jakarta: P.T. Gramedia Pustaka Semesta.

Moleong, L.J. 2010. Metodologi Penelitian Kualitatif, Bandung : Remaja Rosda Karya.

Sugiyono, 2007, Metode \& Teknik Menyusun Proposal Penelitian, Penerbit Alfabeta: Bandung.

Suroso, Rendra., (2004). Material dan Metode Edukasi dari Perspektif Sains Kognitif. Bandung: Bandung Fe Institute. 